\title{
Qualitative Improvement of Therapeutic Glycoproteins by Glycotechnology
}

\author{
糖鎖エ学による医療用タンパク質の質的改善
}

\author{
Tatsunari Nishi and Seiga Itoh \\ Tokyo Research Laboratories, Kyowa Hakko Kogyo Co., Ltd., Tokyo 194, Japan, FAX: 81-427-26-8330
}

Key Words: $G-C S F$, glycotechnology, $t$-PA, plasminogen activator, prourokinase

\begin{abstract}
Recent studies on therapeutic proteins including tissuetype plasminogen activator, erythropoietin, and granulocytemacrophage colony stimulating factor revealed that oligosaccharides attached to them had crucial roles in a variety of biological and physical properties. Our studies on granulocyte colony stimulating factor and prourokinase showed that the designed addition of $\mathrm{N}$-linked oligosaccharide chains on them improved in vitro and in vivo biological properties such as protease susceptibility, thermal stability, and prolongation of in vivo half life.
\end{abstract}

\section{A. Introduction}

Most plasma membrane and secreted proteins of mammalian cells carry oligosaccharide chains, which are attached either at an asparagine residue in the recognition sequence Asn$\mathrm{X}-\mathrm{Thr} / \mathrm{Ser}(N$-linked $)$ or at a serine or threonine residue $(O$ linked). The oligosaccharides of glycoproteins have been shown to influence their biological activities, maintenance of protein conformation, thermal stability, solubility, antigenicity, clearance from the circulation, and protease susceptibility $(1,2)$.

In the 1980's, the development of recombinant DNA technology made it possible to produce large quantities of therapeutic proteins in heterologous host cells such as $E$. coli using their cloned cDNAs. In the early years it was concluded that the procaryote expression system was satisfactory for the production of human therapeutic proteins, because, in the case of many therapeutic proteins such as interferons and interleukins, the nonglycosylated polypeptides have been shown to cause virtually no problem for pharmaceutical use. Later on, however, the oligosaccharide chains of some therapeutic glycoproteins were clearly demonstrated to have considerable effects on their biological properties. For example, the oligosaccharide structures of tissue-type plasminogen activator(tPA), which is used for clot dissolution in myocardial infarction, were shown to influence the biological properties including the clearance rate in the circulation(3-9). Furthermore, in the case of erythropoietin(EPO) which stimulates red cell proliferation and differentiation, the recombinant polypeptide having no $\mathrm{N}$ linked oligosaccharide chain was reported to lose the in vivo
要 旨

組織型プラスミノーゲン活性化因子、エリスロポイエチ ン、そして顆粒球ーマクロファージ・コロニー刺激因子などの 医療用蛋白質に関する最近の研究により、それらに付いている 糖鎖は種々の生物的および物理的性質に重要な役割を果たして いることが明らかになった。顆粒球コロニー刺激因子とプロウ ロキナーゼに関する我々の研究の結果、N-結合型糖鎖を意図的 に付加することにより、プロテアーゼ感受性、熱安定性、in vivo半減期の延長などのin vitroおよびin vivo の生物的諸性質を 改善できることが示された。

A.はじめに

動物細胞の膜蛋白質や分泌蛋白質には糖鎖が結合している ものが多い。糖蛋白糖鎖はAsn-X-Thr/Serなる配列のAsn残基に $\mathrm{N}$-グリコシド結合で付いた $\mathrm{N}$-結合型糖鎖と、ThrまたはSer残基 にO-グリコシド結合で付いたO-結合型糖鎖の2種類に大別され る。糖蛋白糖鎖は、その糖蛋白の生物活性、立体構造の保持、 熱安定性、溶解性、抗原性、血中安定性、そしてプロテアーゼ 感受性などに影響を与えることが明らかにされている $(1 、 2) 。$

1980年代に入り、組換えDNA技術の発展により、医療用蛋 白質を大腸菌などの異種の宿主細胞内で大量生産することが可 能になった。1980年代初期には、インターフェロンやインター ロイキンなどの多くの医療用蛋白質の場合、糖鎖を欠落しても 臨床応用上ほとんど問題を生じなかったことから、医療用蛋白 質を生産するには原核細胞の発現系で十分であると考えられ た。しかしながら、その後、医療用糖蛋白質の中で、その糖鎖 が生物活性に大きな影響を与えることが明確になったものが出 てきた。例えば、心筋梗塞の血栓溶解の治療に用いられる組織 型プラスミノーゲン活性化因子(t-PA)の糖鎖構造は血中でのク リアランス速度を含む生物活性に影響を与えることが示された (3-9)。また、赤血球の分化・成熟を促すエリスロポイエチン (EPO)のように、糖鎖を欠落するとin vivoの生物活性を失う例が 報告された(10-12)。また、最近では、糖蛋白質に結合している 糖鎖の機能が注目を集めている $(1 、 2) 。$

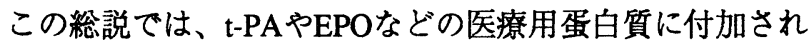


biological activity(10-12). In recent years much more attention has been focused on the role of oligosaccharides of glycoproteins $(1,2)$.

In this review we will summarize the effects of the oligosaccharide chains of therapeutic glycoproteins such as t-PA and EPO on their in vitro and in vivo biological properties. In addition, we will briefly describe our studies on the qualitative improvement of two therapeutic proteins, granulocyte colony stimulating factor(G-CSF) and prourokinase(proUK), by designed addition of $N$-linked oligosaccharides.

\section{B. Effects of Oligosaccharides on Biological and Physical Properties of Therapeutic Glycoproteins}

The administration of recombinant therapeutic proteins to humans requires that the in vivo efficacy comparable to that of the native protein is retained. Therefore, in each case that therapeutic proteins produced by recombinant cells are used for clinical application, both in vitro and in vivo biological properties should be examined carefully. We summarize below the effects which the oligosaccharides of therapeutic proteins such as t-PA, EPO, and granulocytes-macrophage colony stimulating factor(GM-CSF), have on their biological and physical properties.

\section{B-1. Effects on Biological Activities}

Human t-PA carries four potential $N$-glycosylation sites at Asn-117, Asn-184, Asn-218, and Asn-448(13). Very recently human t-PA was found to have an $O$-linked fucose attached to Thr-61 in the epidermal-growth-factor domain, whose functional role was entirely unknown(14). The human tPA polypeptide produced by mammalian cells exists in two variant forms(type I and type II)(15-17). Type I t-PA has three $N$-linked oligosaccharides at Asn-117, Asn-184, and Asn-448, while type II t-PA carries two at Asn-117 and Asn-448. TypeII t-PA, which lacks an $N$-linked oligosaccharide at Asn-184, was reported to have higher specific activity than type I t-PA $(16,18)$. Elimination of both oligosaccharides at Asn-117 and Asn-184 of t-PA using site-directed mutagenesis was shown to result in a threefold increase in specific activity(19). In addition, both type II t-PA and a variant t-PA lacking any $N$-linked oligosaccharide have been shown to have higher fibrin affinity than type I t-PA(19). From these observations, it has been suggested that the oligosaccharides of t-PA attached at Asn-117 and Asn-184 exercise steric effects upon the access of t-PA to a substrate plasminogen or fibrin(19) and prevent the conversion of a single-chain t-PA to a two-chain t-PA $(18,20)$. This steric hindrance by oligosaccharides may be of physiological significance and will be important with respect to therapeutic use of tPA, because a two-chain t-PA activates plasminogen even in the absence of fibrin clot while a single-chain t-PA does not.

Human EPO contains three $N$-linked oligosaccharides at Asn-24, Asn-38, and Asn-83(21-23) and one $O$-linked oligo- ている糖鎖がin vitroおよびin vivoの生物活性に与える影響をま とめると同時に、顆粒球コロニー刺激因子(G-CSF) と血栓溶解 酵素プロウロキナーゼ(proUK)についてN-結合型糖鎖を意図的 に導入することにより、それらの質的改善を試みた我々の研究 を簡単に紹介する。

\section{B．医療用糖蛋白質の生物的および物理的性質に及ぼす糖 鎖の影箘}

遺伝子工学的手法により生産した医療用蛋白質をヒトに投 与する場合、天然型蛋白質と同等のin vivo活性を保持している ことが必要となる。したがって、組換えDNA手法により生産し た医療用蛋白質を治療に用いる個々の場合について、in vitroと in vivoの生物的諸性質を注意媣く調べる必要がある。以下に、 EPO、t-PA、そして顆粒球一マクロファージ・コロニー刺激因 子(GM-CSF)などの医療用蛋白質が持つ糖鎖がそれらの生物的お よび物理的性質に与える影響をまとめる。

\section{B－1．生物活性に与える影第}

ヒトt-PAはAsn-117、Asn-184、Asn-218そしてAsn-448の 4 か所にN-結合型付加部位を有する(13)。ごく最近、ヒトt-PAは その成長因子ドメインのThr-61に0-結合のフコースが付加され ていることが見い出されたが、その機能は全くわかっていない (14)。動物細胞によって生産されるヒトt-PAには2つの型(タイプ IとタイプII)が存在する(15-17)。タイプI・t-PAはAsn-117、Asn184、そしてAsn-448の3ケ所にN-結合型糖鎖が付加されている が、タイプII ・ t-PAはAsn-117とAsn-448に糖鎖を有する。比活 性はAsn-184に糖鎖が付いていないタイプII t-PAの方が高いこと が報告されている(16、18)。部位特異的変異導入法によりAsn117 とAsn-184の糖鎖を同時に欠失すると、比活性が3倍上昇す ることも明らかにされている(19)。さらに、タイプII ・ t-PAとす べての -結合型糖鎖を欠失した $\mathrm{t}-\mathrm{PA}$ 誘導体はタイプI・ t-PAより も高いフィブリン親和性を有することも示されている(19)。こ れらの知見から、Asn-117とAsn-184の糖鎖は高分子基質である プラスミノーゲンあるいはフィブリンが近づくのを立体的に妨 げること(19)、およびt-PAの1本鎖(不活性型)から2本鎖(活性型) への変換を阻害することが示唆されている(18、20)。2本鎖t-PA は1本鎖t-PAとは異なり、フィブリン塊がないときでもプラスミ ノーゲンを活性化してしまうことを考えると、この糖鎖による 立体障害は生理的に重要な意味を持つかもしれないし、またtPAを治療に用いるときに重要になるであろう。

ヒトEPOはAsn-24、Asn-38そしてAsn-83の3ケ所にN-結合 型糖鎖を(21-23)、そしてSer-126の 1 か所にO-結合型糖鎖を有す る(11)。ヒトEPOのN-結合型糖鎖は、t-PAの糖鎖と比べて、そ の生物活性に対してより大きな影響を与えることが証明されて いる。例えば、EPOに付いているすべてのN-結合型糖鎖を欠失 
saccharide at Ser-126(11). The $N$-linked oligosaccharides of EPO have been demonstrated to give more considerable significance to the biological properties, compared to those of t-PA. For example, removal of all the $N$-linked oligosaccharides has resulted in almost complete loss of the in vivo biological activities, while it has been shown to have no significant effect on the in vitro activity, with the exception of an increase in the affinity to EPO receptor $(11,12)$. Desialylation of recombinant EPO was demonstrated to increase its in vitro specific activity threefold $(10,24)$.

Furthermore, in the case of GM-CSF, removal of all the $N$-linked oligosaccharides (attached at Asn-27 and Asn-37) was demonstrated to result in an increase in the specific activity 20 -fold(25). Including these cases, examples are accumulating of oligosaccharides of therapeutic glycoproteins affecting their biological activities.

\section{B-2. Effects on Clearance from the Circulation}

In general the oligosaccharides of glycoproteins markedly affect their clearance rate in the circulation after being injected intravenously. Carbohydrate-specific receptors and glomerular filtration in the kidneys are involved in such clearance. Among the carbohydrate-specific receptors for the clearance, there have been many studies on the asialoglycoprotein receptor on hepatocytes (recognizing galactose residues made terminal by removal of sialic acid) and the mannose receptor present on resident macrophages (recognizing mannose and fucose)(26).

In the case of the clearance in the kidneys, both molecular mass and surface charge of proteins influence the filtration through the kidneys $(2,27)$. Especially for glyproteins of lowmolecular weight, the presence of oligosaccharides on the proteins is known to inhibit their clearance in the kidneys through increased size and/or negative charge of sialic acids on the oligosaccharides.

In the case of ciearance of t-PA from the blood stream, there have been many reports about a specific receptor for t-PA present mainly in the liver which binds to the epidermalgrowth-factor domain of t-PA(28-31). Further, the clearance of t-PA is shown to be influenced by the oligosaccharide structures, particularly by the high mannose oligosaccharide chain attached to Asn-117(5, 6). For example, removal or modification of the oligosaccharide at Asn-117 of t-PA prolongs the half-life time, which is presumably due to prevention of the recognition by the mannose receptor $(5,6)$. In addition, removal of the oligosaccharide at Asn- 448 also was reported to reduce the clearance rate by an unknown mechanism(3). In the case of recombinant human EPO, which is slowly cleared from the circulation, the sialic acid of the EPO is thought to contribute to stable circulation, because asialo-EPO was rapidly taken up by the asialoglycoprotein receptor in the liver $(32,33)$. In addition, Fukuda, et al.(32) have reported that the recombinant するとin vivoの活性がほとんどなくなる。ただし、このN-結合 型糖鎖の欠失はin vitroの活性に対しては大きな影響を与えず、 むしろEPOレセプターへの親和性を向上させることが知られて いる(11、12)。組換えEPOを脱シアロ化すると、むしろin vitro の活性は約3倍上昇することも報告されている(10、24)。

さらに、GM-CSFの場合には、Asn-27とAsn-37の2か所の $\mathrm{N}$-結合型糖鎖を欠失すると比活性が約20倍も上昇することが証 明された(25)。このように、糖鎖が医療用蛋白質の生物活性に 大きな影響を与える例が集積してきた。

\section{B - 2. 血中クリアランスに与える影䈏}

一般的に、糖蛋白質の糖鎖はその糖蛋白質の静脈内投与後 のクリアランス速度に大きな影響を与える。そのクリアランス には糖鎖特異的レセプターや腎系球体での滤過が関与してい る。血中クリアランスに関与する糖鎖特異的レセプターとして は、肝細胞上のアシアロ糖蛋白質レセプター(シアル酸がはずれ て露出したガラクトース残基を認識する)と固着のマクロファー ジに存在するマンノースレセプター(マンノースとフコースを認 識する)がょく研究されている(26)。腎蔵でのクリアランスの場 合には、蛋白質の分子量と表面荷電が腎臓での濾過に大きな影 響を与える(2、27)。特に低分子の糖蛋白質については、蛋白質 上の糖鎖の存在が、分子の大きさの増大への寄与および(また は)糖鎖に付加しているシアル酸の負電荷の増大への寄与によ り、腎蔵でのクリアランスを阻害することが知られている。 t-PAの血中クリアランスの場合には、主に肝臓に存在し、 かつt-PAの成長因子ドメインに結合するt-PA特異的レセプター に関する報告が数多くなされている(28-31)。さらに、t-PAのク リアランスはその糖鎖構造、特にAsn-117に付加されている高マ ンノース型糖鎖によって影響を受けることが示されている(5、

6)。例えば、Asn-117に付加されている糖鎖を修飾すると血中半 隇期が延長するが、これはおそらくマンノースレセプターによ る認識を妨げるためであろう(5、6)。さらに、機構は不明であ るが、t-PAのAsn-448に付加されている糖鎖を除去するとクリア ランス速度が減少することが報告されている(3)。血中から消失 する速度が遅いヒト組換えEPOの場合には、アシアロEPOが肝 臓のアシアロ糖蛋白質レセプターにより速やかに捕捉されるこ とから、EPOに付加されているシアル酸がその血中安定性に寄 与していると考えられる(32、33)。さらに、福田らは、ポリラ クトサミン構造を持つN-結合型糖鎖を含むとト組換えEPOもま た、アシアロ糖蛋白質レセプターにより肝臓で速やかに消失を 受けることを報告している(32)。GM-CSFの場合は、クリアラン スが起こる主な部位は腎葴であり、 $\mathrm{N}$-結合型糖鎖の欠落が腎 臟からのクリアランスを助長することが証明されている(34)。

\section{B - 3 . 熱安定性}

糖蛋白糖鎖が蛋白質の熱安定性に寄与していることはよく 
EPO containing the $N$-linked oligosaccharides with $N$-acetyllactosamine repeats was also cleared rapidly in the liver through the asialoglycoprotein receptor. In the case of GMCSF, it was demonstrated that elimination of its $N$-linked oligosaccharides facilitated its clearance through the kidneys which were the major site of its clearance(34).

\section{B-3. Thermal Stability}

The oligosaccharides of glycoproteins are well known to affect their thermal stability. In the cases of EPO and GCSF, $N$-linked and $O$-linked oligosaccharides have been reported to contribute to their thermal stability, respectively(35, 36).

\section{Qualitative Improvement of G-CSF by Designed Attach- ment of Oligosaccharides}

G-CSF which is a therapeutic protein is used to elevate the concentration of leukocytes decreased by cancer chemotherapy. The native human G-CSF carries no $N$-linked oligosaccharide, while it contains an $O$-linked oligosaccharide $(37$, 38). This is supported by the absence of the $N$-glycosylation site (Asn-X-Thr/Ser) in the primary sequence $(37,39)$. Therefore, to examine the effect of adding $N$-linked oligosaccharides on the biological properties of G-CSF, we have attempted to express four human G-CSF variants each having an $\mathrm{N}$-glycosylation site at amino acid positions $6,23,145$, or 162 (designated as
知られているが、EPOとG-CSFについても、それぞれN-結合型 糖鎖とO-結合型糖鎖が熱安定性に寄与していることが報告され ている(35、36)。

\section{C. 意㘡的糖鎖導入による G-CSFの質的改善}

顆粒球への分化・成熟を促すG-CSFは制癌剤の投与により 減少した白血球の数を回復させるために用いられている医療用 蛋白質である。天然型とトG-CSFはO-結合型糖鎖を有している

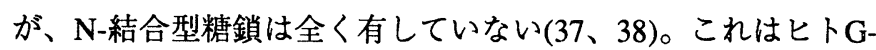
CSFの一次配列中にN-結合型糖鎖付加配列(Asn-X-Thr/Ser)が存 在しないことでも明らかである(37、39)。そこで、我々は、G$\mathrm{CSF}$ ○N-結合型糖鎖の付加がその生物活性にどのような影響 を及ほすかを調べるために、そのハイドロパシープロフィール から判断して外側に露出していると推測される領域に存在する 6位、23位、145位、あるいは162位のアミノ酸残基にN-結合型 糖鎖付加部位を導入した4種類のG-CSF誘導体(それぞれN6、 N23、N145、N162 と名付けた)(図1)を発現させることを試み た。比活性が向上したヒト G-CSF誘導体であるKW2228[Thr-1 $\rightarrow$ Ala, Leu-3 $\rightarrow$ Thr, Gly-4 $\rightarrow$ Tyr, Pro-5 $\rightarrow$ Arg, Cys-17 $\rightarrow$ Ser] (40)に部位 特異的変異を導入することにより、それぞれの誘導体をコード する遺伝子を造成し、SV40初期プロモーターの制御下で遺伝子 発現を促すpSE1PA1SE1dhfr1-9Aベクター(ジヒドロ葉酸レダク

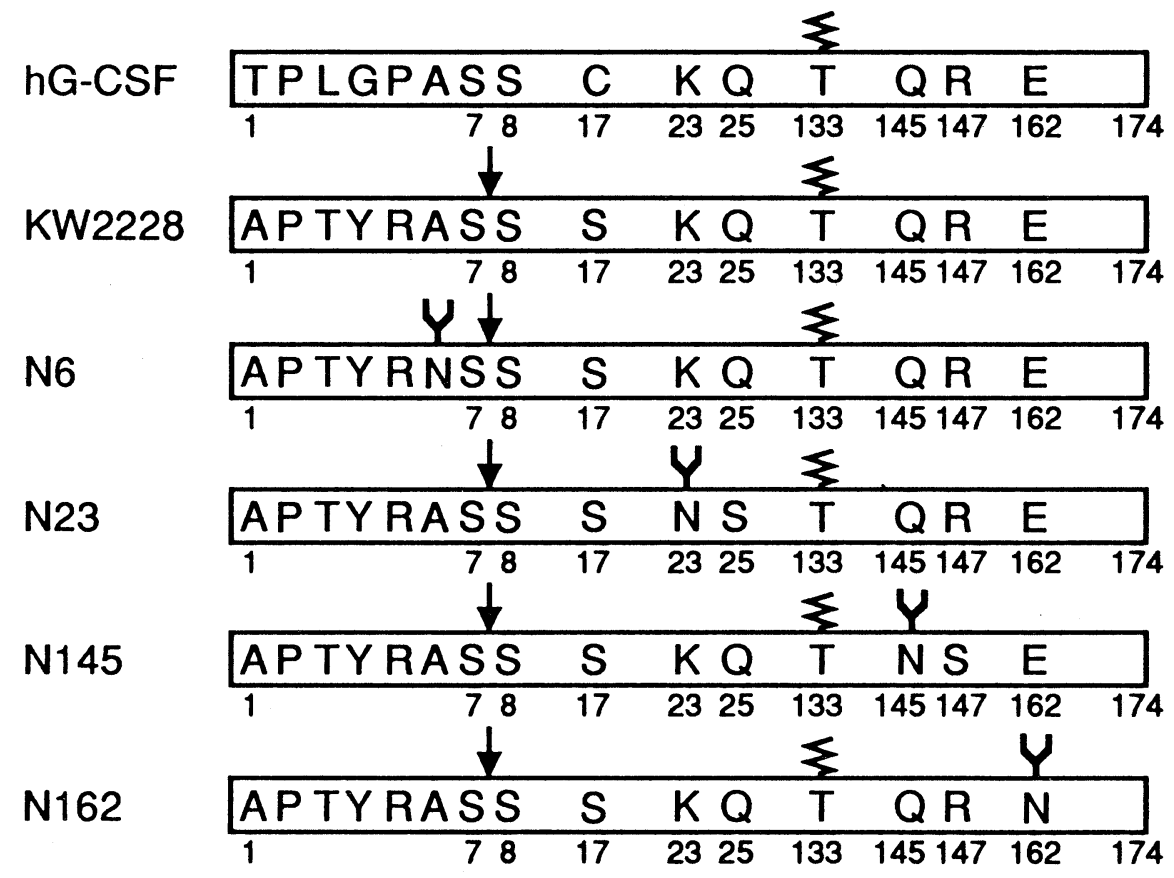

Fig. I. Structures of human G-CSF variants.

$Y=N$-linked oligosaccharides; $\xi=O$-linked oligosaccharides;

$\downarrow=$ potential subtilicin BPN' cleavage sites 
$\mathrm{N} 6, \mathrm{~N} 23, \mathrm{~N} 145$, and $\mathrm{N} 162$, respectively) which are expected to be located on the surface region of the protein by judging from the hydropathy profile(Fig. 1). The genes encoding each variant were constructed using site-directed mutagenesis of an improved G-CSF mutein named KW2228 [Thr- $1 \rightarrow$ Ala, Leu-3 $\rightarrow$ Thr, Gly-4 $\rightarrow$ Tyr, Pro- $5 \rightarrow$ Arg, Cys-17 $\rightarrow$ Ser](40), and were inserted into pSE1PA1SE1dhfr 1-9A, a derivative of pSE1 $\beta \mathrm{d} 2$ 4(a mammalian expression vector with the dihydrofolate reductase gene)(41), in which the expression of the inserted gene is driven from an SV40 early promoter. After the Chinese hamster ovary (CHO)-DHFR- cells were transfected with each of these resulting plasmids, the recombinant cells were selected by G418 resistance. The cell lines expressing high levels of GCSF variants except $\mathrm{N} 23$ were obtained by methotrexate resistance. In contrast, the productivity of the cell line expressing N23 which was obtained by the same procedure, was considerably lower compared to those of N6, N145, or N162. As for N6, N23, and N145, 30 to $50 \%$ of the G-CSF polypeptide expressed was glycosylated, whereas the N162 polypeptide was not efficiently glycosylated, suggesting that factors including steric hindrance affect attachment or processing of $N$-linked oligosaccharide chains.

Subsequently, to clarify the change in the biological properties due to the addition of $N$-linked oligosaccharides, we have separated $N$-glycosylated and non $N$-glycosylated N6 proteins. First of all, these two forms of proteins were examined for their specific activity by two different methods using NSF60 cells and bone marrow cells of $\mathrm{C} 3 \mathrm{H} / \mathrm{He}$ mice, respectively $(42,43)$ to show virtually no difference in specific activity between these two forms. Second, in respect of thermal stability, $N$-glycosylated N6 was observed to be more stable against thermal inactivation than non $\mathrm{N}$-glycosylated N6, after incubation for a variety of periods $(30 \mathrm{~min}$. to $5 \mathrm{hrs})$ at $55^{\circ} \mathrm{C}$ or $65^{\circ} \mathrm{C}$ in phosphate-buffered solution. For example, the residual activity of $\mathrm{N}$-glycosylated N6 after incubation for 1 hour at $65^{\circ} \mathrm{C}$ was approximately $40 \%$ whereas that of non $N$-glycosylated N6 was about $15 \%$.

When the N6 protein was produced in $E$. coli, protein degradation in the $\mathrm{N}$-terminal portion was found which was never observed in the native human G-CSF protein. The structural analysis revealed that this degradation resulted from the difference in the amino acid sequence of the $\mathrm{N}$-terminal portion between them. In addition, subtilisin BPN' was found to cleave the peptide bond between the seventh and eighth residues(Fig. 1), which urged us to examine possible differences in subtilisin BPN' susceptibility between $N$-glycosylated and non $N$-glycosylated N6 proteins produced in $\mathrm{CHO}$ cells. Incubation of non $N$-glycosylated N6 proteins $(20 \mu \mathrm{g} / \mathrm{ml})$ with subtilisin BPN'(4 $\mathrm{ng} / \mathrm{ml}$ ) at $37^{\circ} \mathrm{C}$ for $3 \mathrm{hrs}$ resulted in protein degradation of the $\mathrm{N}$-terminal portion, whereas $\mathrm{N}$-glycosylated $\mathrm{N} 6$ protein was not degraded even after incubation for $72 \mathrm{hrs}$ under the same condi-
ターゼ遺伝子を運ぶ動物細胞発現ベクターで、pSE1ßd2-4の誘 導体)(41)に組み込んだ。このようにして造成したプラスミドを チャイニーズハムスター子宮(CHO)-DHFR-細胞に導入した後、 組換え細胞株をG418耐性によって選択した。N23以外の誘導体 を大量に発現する細胞株をメトトレキセート耐性によって取得 した。一方、同じ方法により得たN23を発現する細胞株の生産 性はN6、N145、N162の生産性と比べてはるかに低かった。 N6、N23、そしてN145については、N-結合型糖鎖が付いたGCSFポリペプチドの割合は全体の30〜50\%であったが、N162ポ リペプチドはN-結合型糖鎖が結合したものの割合が極端に低 かった。このことは、立体障害を含む要因がN-結合型糖鎖の結 合または形成に大きく影響することを示唆する。

続いて、N-結合型糖鎖の導入により生物的諸性質がどのよ うに変化するかを明らかにするため、N-結合型糖鎖が付加した N6蛋白質と付加していないN6蛋白質をそれぞれ精製・分離し た。まず最初に、これら2つの型の蛋白質について、NSF60細胞 と $\mathrm{C} 3 \mathrm{H} / \mathrm{He}$ マウスの骨髄細胞を用いる2つの方法(42、43)により 比活性を調べたところ、これら2つの型の間に比活性の差はほと んどないことがわかった。第2に、熱安定性については、リン酸 緩衝液中 $55^{\circ} \mathrm{C}$ たは $65^{\circ} \mathrm{C} て ゙$ 種々の時間(30分〜 5 時間)の加熱処理 を行ったところ、N-結合型糖鎖を持つN6蛋白質はN-結合型糖鎖 を持たないN6蛋白質よりも熱失活に対して安定であることが観 察された。たとえば、 $65^{\circ} \mathrm{C} て ゙ 1$ 時間の加熱処理を加えたN-結合 型糖鎖を持つN6の残存活性は約 $40 \%$ あっただ、N-結合型糖鎖 を持たないN6の残存活性は約15\%であった。

大腸菌内でN6蛋白質を生産したときに、天然型ヒトG-CSF では認められなかったN末端部分の蛋白質分解が見い出され た。その構造解析の結果、この分解は両者の間のN末端部分の アミノ酸配列の相違に起因することがわかった。さらに、サチ ライシンBPNが7番目と8番目のアミノ残基の間のペプチド結合 を切断することがわかり(図 1)、我々はCHO細胞で生産したN結合型糖鎖を持つN6蛋白質とN-結合型糖鎖を持たないN6蛋白 質の間のサチライシン BPN'感受性の違いを調べることにした。 $\mathrm{N}$-結合型糖鎖を持たないN6蛋白質 $(20 \mu \mathrm{g} / \mathrm{ml})$ にサチライシン $\mathrm{BPN}^{\prime}(4 \mathrm{ng} / \mathrm{ml})$ を加えて $37^{\circ} \mathrm{C} て ゙ 3$ 時間保温したところ、N末端部分 の蛋白質分解が起こったが、N-結合型糖鎖を持つN6蛋白質は同 じ条件下で72時間以上保温しても分解が認められなかった。

以上のように、ヒトG-CSF変異蛋白質KW2228にN-結合型 糖鎖を人為的に付加することにより、その比活性を低下させず に、熱安定性やプロテアーゼ抵抗性などの生物的および物理的 諸性質を改善できることが示された(佐々木ら、投稿中)。

\section{D. 意図的 $\mathrm{N}$-結合型糖鎖の付加によるproUKの留的改善} proUK(ウロキナーゼの1本鎖前駆体)は、 $\mathrm{t}-\mathrm{PA}$ 少うに効率 
tions.

Taken together, designed attachment of the $N$-linked oligosaccharides on human G-CSF mutein KW2228 has been shown to improve its biological and physical properties such as thermal stability and protease resistance without any alternation of specific activity(Sasaki et al., submitted).

\section{Qualitative Improvement of proUK by Designed Attach- ment of $N$-Linked Oligosaccharides}

proUK(a single-chain precusor molecule of urokinase) is one of the plasminogen activators which promotes efficient thrombolysis as t-PA. proUK activates plasminogen directly with low activity, whereas it is converted to urokinase(a more active two-chain form) by cleavage of the Arg-156 - Phe- 157 peptide bond according to the following three successive reactions: (I) proUK converts an inactive proenzyme plasminogen to an active serine protease plasmin; (II) the resulting plasmin converts proUK to urokinase; and (III) the generated urokinase activates plasminogen(44).

A prominent example demonstrating the influence of the biological activities of therapeutic proteins by proteases in the blood, is the inactivation of proUK by thrombin, a protease involved in fibrin formation. In contrast to activation of proUK by plasmin treatment, proUK has been shown to be converted to an inactive two-chain form when treated with thrombin(4547). In this case, thrombin cleaves the Arg-156 - Phe- 157 bond located at two amino acid residues in the $\mathrm{N}$-terminal direction of the plasmin cleavage site(45). The resulting two-chain urokinase is resistant to activation with plasmin. Taking into account that thrombin accelerates clot forming, inactivation of proUK by thrombin may downregulate the lysis of a freshly formed clot, suggesting a physiological significance.

Inactivation of proUK by thrombin may be a disadvantage when proUK is used for clot dissolution through intravenous injection. To overcome this disadvantage, we generated a few variants which acquired thrombin resistance by means of alternation of Phe-157. However, such alternation affected the rate for cleavage by plasmin to result in decrease in specific activity(Yasumura, unpublished results). As an attempt to obtain thrombin-resistant proUK derivatives without any loss of specific activity, we have generated proUK variants with an $\mathrm{N}$ linked oligosaccharide chain near the thrombin cleavage site of proUK.

The genes encoding each of two proUK variants, proUK-S1 [Phe-164 $\rightarrow$ Thr] and proUK-S3 [Leu-153 $\rightarrow$ Asn, Pro-155 $\rightarrow$ Thr](Fig. 2), were constructed which carried $N$-glycosylation sites at positions 164 or 153 , respectively, and were inserted into the expression vector pSE1PA1SE1dhfr1-9A (described above). Subsequently, the polypeptides of these variants were produced in large quantities in recombinant $\mathrm{CHO}$ cells according to the same procedure as the production of G-
のよい血栓溶解を促すことができるプラスミノーゲン活性化因 子の1つである。proUKは低活性ではあるがプラスミノーゲンを

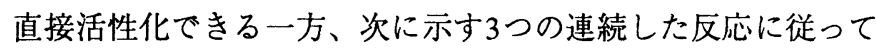
Lys-158とIle-159の間のペプチド結合が切断されることによりウ ロキナーゼ(より活性の強い2本鎖型)に変換される。すなわち、 (I) proUKは不活性型の前駆体酵素であるプラスミノーゲンを活 性型セリンプロテアーゼであるプラスミンに変換し、(II) 生じた プラスミンはproUKをウロキナーゼに変換し、そして(III)生成 したウロキナーゼはプラスミノーゲンを活性化する(44)。

血中に存在するプロテアーゼが医療用蛋白質の活性に及は す影響を示している明確な例は、フィブリン形成に関与するプ ロテアーゼであるトロンビンによる proUKの不活性化である。 proUKは、プラスミン処理による活性化とは異なり、トロンビ ンで処理したときには不活性型の2本鎖に変換することが示され た(45-47)。この場合、トロンビンはproUKのプラスミン切断部 位から2アミノ酸残基だけN末端側のArg-156-Phe-157の間の結 合を切断する(45)。その結果生じた2本鎖ウロキナーゼはプラス ミンによる活性化を受けにくくなる。トロンビンは血栓形成を 促進することを考えると、proUKのトロンビンによる不活性化 は新しく生成した血栓の溶解を遅延させるという生理的意義を 示唆しているのかもしれない。

トロンビンによるproUKの不活性化はproUKを静脈内投与 により血栓溶解に用いる際に久点となるかもしれない。この久 点を改善するため、Phe-157の変異によりトロンビン抵抗性を示 す変異体を造成した。しかしながら、そのような変異はプラス ミンによる切断速度に影響を与えるために比活性の低下を引き 起こした(安村ら、未発表)。我々は、比活性の低下を引き起こ さないトロンビン抵抗性proUK誘導体を取得する試みとして、 pro-UKのトロンビン切断活性部位近傍に $\mathrm{N}$-結合型糖鎖を持つ proUK誘導体を造成した。

164位あるいは153位にN-結合型糖鎖付加部位を導入した2 種のproUK誘導体、proUK-S1 [Phe-164 $\rightarrow$ Thr] とproUK-S3 [Leu-

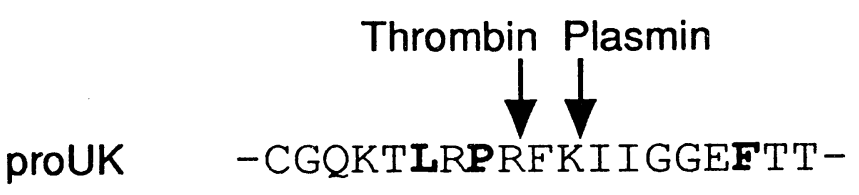

proUK-S1

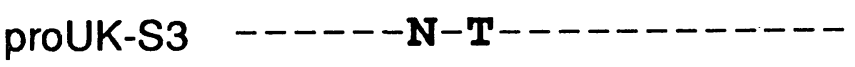

Fig. 2. Amino acid sequences near the thrombin and plasmin cleavage sites of proUK and its variants.

(c)1992 FCCA (Forum: Carbohydrates Coming of Age) 
CSF variants, followed by purifying with immunoaffinity chromatography using immobilized anti-urokinase monoclonal antibody. Both of the purified proUK-S1 and proUK-S3 glyproteins were properly $\mathrm{N}$-glycosylated at more than $90 \%$. The specific activity of proUK-S1 was shown to be similar to that of the native proUK, while proUK-S3 had about three times higher specific activity than of the native proUK. To thermal inactivation, proUK-S3 was more stable than the native proUK, while the thermal stability of proUK-S1 was almost equal to that of the native proUK. The reason for this discrepancy is unknown. In addition, both were much more resistant to inactivation by thrombin than the native proUK. The thrombin resistance of proUK-S1 was proved to result from the acquisition of $N$-linked oligosaccharide chain near the thrombin cleavage site, because the proUK-S1 protein lacking the oligosaccharide chain at position 164 was susceptible to thrombin cleavage. In contrast, it is undetermined whether the occupancy of an $N$-linked oligosaccharide chain contributes to thrombin resistance of proUK-S3, since even amino acid replacement at residue 155 (Pro-155 $\rightarrow$ Thr) itself was found to confer thrombin resistance to proUK. With respect to plasmin susceptibility, the attachment of an $N$-linked oligosaccharide chain near the plasmin cleavage site had little effect on the susceptibility of proUK-S1, whereas that attachment significantly reduced the susceptibility of proUK-S3. This may imply that thrombin has access to proUK from a different direction from plasmin. For in vitro lysis of blood clot made by addition of thrombin in human serum, both proUK-S1 and proUK-S3 were superior to the native proUK. Subsequently, purified proUK-S1 glycoprotein was examined for the efficacy in in vivo clot lysis, proving that proUK-S1 dissolved blood clot more efficiently than the native proUK. Furthermore, proUK-S1 was improved in the following in vivo properties, compared to the native proUK. It is revealed that the in vivo half life of proUK-S1 in dogs was significantly prolonged compared to the native proUK. Prolongation of the half life of plasminogen activators usually accelerates systemic plasminogen activation and fibrinogenolysis, while essentially no changes in levels of $\propto 2$ plasmin inhibitor, fibrinogen, and plasminogen, were observed with administration of proUK-S1.

Taken together, the attachment of $N$-linked oligosaccharide chains near the thrombin and plasmin cleavage sites of proUK was demonstrated to improve several biological properties including the in vivo clot lysis in addition to acquisition of thrombin resistance with little reduction of specific activity (Yasumura et al, manuscript in preparation).

\section{E. Concluding Remarks}

As described above, the effects of the $N$-linked oligosaccharides on the biological properties of therapeutic proteins
$153 \rightarrow$ Asn, Pro-155 $\rightarrow \mathrm{Thr}$ (図2)をコードする遺伝子を造成し、上 述の発現ベクターpSE1PA1SE1dhfr1-9Aに挿入した。続いて、 G-CSF誘導体の生産と同じ手法を用いて、これら誘導体のポリ ペプチドを組換えCHO細胞で大量生産した後、固定化した抗ウ ロキナーゼ・モノクローナル抗体を用いたイムノアフィニ ティーカラムクロマトグラフィーにより精製した。精製した proUK-S1 と proUK-S3糖蛋白質はともに $90 \%$ 以上の効率で目的の 部位に糖鎖が付加されていた。proUK-S1の比活性は天然型 proUKのものと同等であったが、pro-UK-S3は天然型proUKの約 3倍の比活性を有していることがわかった。熱失活に対しては、 proUK-S3は天然型proUKより安定であったが、proUK-S1の熱安 定性は天然型proUKと同程度であった。このような違いが生じ る理由は不明である。加えて、両方とも天然型proUKに比べて トロンビンによる不活性化に対してはかなり耐性であった。164 位に糖鎖が付加されていないproUK-S1蛋白質はトロンビン切断 に対して感受性を示すことから、トロンビン切断部位近傍にN結合型糖鎖が付加された結果、proUK-S1はトロンビン耐性を獲 得したといえる。これに対して、155位のアミノ酸置換（Pro$155 \rightarrow \mathrm{Thr})$ のみでproUKはトロンビン耐性を獲得することが見 い出されたことから、N-結合型糖鎖の付加がproUK-S3のトロン ビン耐性に寄与しているかどうかについてはわからない。プラ スミン感受性については、プラスミン切断部位近傍へのN-結合 型糖鎖の付加はproUK-S1のプラスミン感受性にはほとんど影響 を与えなかったが、proUK-S3のプラスミン感受性は有意に減少 した。このことは、トロンビンはプラスミンと異なる方向から pro-UKに近づくことを意味するのかもしれない。ヒト血清にト ロンビンを添加することにより調製した血栓のin vitro溶解につ いては、proUK-S1と proUK-S3はともに天然型proUKよりもすぐ れた活性を示した。続いて、 proUK-S1糖蛋白質について in vivo での血栓溶解能を調べたところ、proUK-S1は天然型proUKより も効率よく血栓を溶解することがわかった。さらに、proUK-S1 は天然型proUKと比べて以下のin vivoの諸性質が改善されてい た。犬における proUK-S1のin vivo半隇期は天然型proUKと比心゙ て有意に延長していることが判明した。なお、通常、プラスミ ノーゲン活性化因子の半減期の延長は全身性プラスミノーゲン 活性化とフィブリノーゲン溶解を引き起こすが、 $\alpha 2$-プラスミ ン・インヒビター、フィブリノーゲン、およびプラスミノーゲ ンの濃度はproUK-S1の投与によってほとんど変化しなかった。

以上のように、proUKのトロンビンとプラスミンの切断部 位の近傍にN-結合型糖鎖を導入することにより、比活性を低下 させずにトロンビンに対する抵抗性が獲得されただけでなく、 in vivoの血栓溶解を含むいくつかの生物的諸性質が改善される ことが証明された(安村ら、投稿準備中)。 
have been studied in detail mainly for t-PA, EPO, and GMCSF. However, there has been almost no report on attempts to improve their biological properties and efficacy by designed addition of oligosaccharide chains. Therefore we have studied the effects which $N$-linked oligosaccharide chains attached designedly on G-CSF or proUK, had on their biological properties and efficacy. As described here, designed introduction of $\mathrm{N}$ glycosylation sites(Asn-X-Thr/Ser) into the coding sequences of G-CSF or proUK has been shown to lead to efficient addition of $\mathrm{N}$-linked oligosaccharide chains, resulting in acquisition of protease resistance, improvement in thermal stability, and extension of in vivo half-life.

The factors influencing the oligosaccharide processing are poorly understood. Our preliminary results have shown that the condition for cultivation of recombinant animal cells producing proUK variants affected their oligosaccharide structures. In the future, the accumulation of theoretical rules with development in glycoscience will allow rational improvement of therapeutic glycoproteins using glycotechnology. In recent years, there have been many studies on animal lectins, especially C-type lectins(48) including selectins(49-51), which recognize specific carbohydrate structures. Therefore, targeting of therapeutic proteins at specific organs and sites will be made possible by the acquisition of specific carbohydrate-epitopes which are recognized by lectins expressed there. For this purpose, there is a need to construct animal host cells expressing specific glycosyltransferases. Recent progress in molecular biology has made possible the isolation of more than six glycosyltransferase genes(52). And the number of cloned genes will be increasing exponentially. In the near future, advances in glycoscience and glycotechnology will realize the desired and easy alternation of oligosaccharide structures.

\section{E .おわりに}

上述のように、 $\mathrm{N}$-結合型糖鎖が医療用蛋白質の生物的諸性 質に及はす影響については、これまで主にt-PA、EPOそして GM-CSFについて詳しい解析がなされている。しかしながら、 意図的な糖鎖付加によって医療用蛋白質の生物的諸性質や効能 の改善を試みた報告はほとんどなされていなかった。そこで、 我々は、G-CSFあるいはproUKに意図的に付加したN-結合型糖 鎖がそれらの生物的諸性質や効能に及ほす影響を調べた。ここ で述べたように、G-CSFまたはproUKの翻訳配列内にN-結合型 糖鎖付加部位を導入することにより $\mathrm{N}$-結合型糖鎖を効率よく付 加できることがわかり、その結果、プロテアーゼ抵抗性の獲 得、熱安定性の改善およびin vivo半減期の延長に結び付くこと が明らかになった。

糖鎖の構造形成に影響を及ほす因子についてはあまり解析 が進んでいない。我々の予備的な結果では、proUK誘導体を生 産する組換え動物細胞の培盖条件がその糖鎖構造に影響を与え ることが示された。将来、糖鎖科学の発展により論理的な法則 が集積することにより、糖鎖工学を用いて医療用糖蛋白質を理 論的に改善できるようになるであろう。近年、特定の糖鎖エピ トープを認識する動物レクチン、特にセレクチン(49-51)を含む C型レクチン(48)に関して研究が進んでいる。したがって、医療 用蛋白質を特定の臓器や部位に集積させることは、そこで発現 しているレクチンによって認識される特定の糖鎖エピトープを 導入することにより可能になるであろう。このためには、特定 の糖転移酵素を発現している宿主細胞を造成する必要がある。 分子生物学の最近の進歩により、6個以上の糖転移酵素遺伝子が 単離された $(52)$ 。今後その数は指数関数的に増加するであろ う。近い将来、糖鎖科学と糖鎖工学の発展により、糖鎖の構造 を自由にしかも簡単に改変できるようになるであろう。

\section{References}

1. Rademacher, T.W., Parekh, R.B., and Dwek, R.A. (1988) Ann. Rev. Biochem. 57, 785-838

2. Goochee, C.F., Gramer, M.J., Anderson, D.C., Bahr, J.B., and Rasmussen, J.R. (1991) Biotechnology 9, $1347-1355$

3. Lau, D., Gregory., K., Wei, C.-M., Livingston, D.J., and Hsiung, N. (1987) Biotechnology 5, 953-958

4. Collen, D., Stassen, J.-M., and Larsen, G. (1988) Blood 71, 216-219

5. Hotchkiss, A., Refino, C.J., Leonard, C.K., O'Connor, J.V., Crowley, C., McCabe, J., Tate, K., Nakamura, G., Poweres, D., Levinson, A., Mohler, M., and Spellman, M.W. (1988) Thromb. Haemotasis 52, 308-311

6. Tanswell, P., Schlüter, M., and Krause, J. (1989) Fibrinolysis 3, 79-84

7. Warren, T., Wun, T.-C., Hebert, B., Reitz, B., Palmier, M., Ramabhadran, T., and Tiemeier, D.C. (1989) Biochemistry 28, $7670-7679$

8. Wittwer, A. J., Howard, S. C., Carr, L. S., Harakas, N. K., and Feder, J. (1989) Biochemistry 28, 7662-7669

9. Parekh, R.B., Dwek, R.A., Rudd, P.M., Thomas, J.R., Rademacher, T.W., Wittwer, A.J., and Howard, S.C. (1990) Biochemistry 29, $4175-4180$

10. Takeuchi, M., Inoue, N., Strickland, T.W., Kubota, M., Wada, M., Shimizu, R., Hoshi, S., Kozutsumi, H., Takasaki, S., and Kobata, A. (1989) Proc. Natl. Acad. Sci. USA 86, 7819-7822

11. Tsuda, E., Kawanishi, G., Ueda, M., Masuda, S., and Sasaki, R. (1990) Eur. J. Biochem. 188, 405-411

12. Yamaguchi, K., Akai, K., Kawanishi, G., Ueda, M., Masuda, S., and Sasaki, R. (1991) J. Biol. Chem. 266, 20434-20439

13. Pennica, D., Holmes, W.E., Kohr, W.J., Harkins, R.N., Vehar, G.A., Ward, C.A., Bennett, W.F., Yelverton, E., Seeburg, P.H., Heyneker, H.L., and Goeddel, D.V. (1982) Nature 301, 214-221

14. Harris, R.J., Leonard, C.K., Guzzetta, A.W., and Spellamn, M.W. (1991) Biochemistry 30, 2311-2314

15. Pohl, G., Källström, M., Bergsdorf, N., Wallén, and Jörnvall, H. (1984) Biochemistry 23, 3701-3707

16. Einarsson, M., Brandt, J., and Kaplan, L. (1985) Biochem. Biophys. Acta 580, 140-153 
17. Spellman, M.W., Basa, L.J., Leonard, C.K., Chakel, J.A., O'Connor, J.V., Wilson, S., and van Halbeek, H. (1989) J. Biol. Chem. 264, $14100-14111$

18. Wittwer, A.J., Howard, S.C., Carr, L.S., Harakas, N.K., and Feder, J. (1989) Biochemistry 28, 7662-7669

19. Haigwood, N.L., Mullenbach, G.T., Moore, G.K., DesJardin, L.E., Tabrizi, A., Brown-Shimer, S.L., Stauß, H., Stöhr, H.A., and Pâques, E.-P. (1989) Protein Engineering 2, 611-620

20. Wittwer, A.J., and Howard, S.C. (1990) Biochemistry 29, 4175-4180.

21. Jacobs, K., Shoemaker, C., Rudersdorf, R., Neill, S.D., Kaufman, R.J., Mufson, A., Seehra, J., Jones, S.S., Hewick, R., Fritch, E.F., Kawakita, M., Shimizu, T., and Miyake, T. (1985) Nature 313, 806-810

22. Lin, F.-K., Suggs, S., Lin, C.-H., Browne, J.K., Smalling, R., Egrie, J.C., Chen, K.K., Fox, G.M., Martin, F., Stabinsky, Z., Badrawi, S.M., Lai, P.-H., and Goldwasser, E. (1985) Proc. Natl. Acad. Sci. USA 82, 7580-7584

23. Lai, P.-H., Everett, R., Wang, F.-F., Arakawa, T., and Goldwasser, E. (1986) J. Biol. Chem. 261, 3116-3121

24. Takeuchi, M., Takasaki, S., Shimada, M., and Kobata, A. (1990) J. Biol. Chem. 265, 12127-12130

25. Moonen, P., Mermod, J.-J., Ernst, J.F., Hirschi, M., and DeLamarter, J.F. (1987) Proc. Natl. Acad. Sci. USA 84, $4428-4431$

26. Ashwell, G., and Harford, J. (1982) Ann. Rev. Biochem. 51, 531-554

27. Gross, V., Heinrich, P.C., vom Berg, D., Steube, K., Andus, T., Tran-Thi, T.-A., Decker, K., and Gerok, W. (1988) Eur. J. Biochem. 173, 653-659

28. Krause, J., Seydel, W., Heinzel, G., Tanswell, P. (1990) Biochem. J. 267, 647-652

29. Owensby, D.A., Sobel, B.E., and Schwartz, A.L. (1988) J. Biol. Chem. 263, 10587-10594

30. Kuiper, J., Otter, M., Rijken, D.C., and van Berkel, T.J.C. (1988) J. Biol. Chem. 263, 18220-18224

31. Bakhit, C., Lewis, D., Nilsson, B., and Malfroy, B. (1987) J. Biol. Chem. 262, 8716-8270

32. Fukuda, M.N., Sasaki, H., and Fukuda, M. (1989) Blood 73, 84-89

33. Spivak, J.L., and Hogans, B.B. (1989) Blood 73, 90-99

34. Donahue, R.E., Wang, E.A., Kaufman, R.J., Foutch, L., Leary, A.C., Witek-Giannetti, J.S., Metzger, M., Hewick, R.M., Steinbrink, D.R., Shaw, G., Kamen, R., and Clark, S.C. (1986) Cold Spring Harbor Symp. Quant. Biol. 51, 685-692

35. Narhi, L.O., Arakawa, T., Aoki, K.H., Elmore, R., Rohde, M.F., Boone, T., and Strickland, T.W. (1991) J. Biol. Chem. 266, 23022-23026

36. Oh-eda, M., Hasegawa, M., Hattori, K., Kuboniwa, H., Kojima, T., Orita, T., Tomonou, K., Yamazaki, T., and Ochi, N. (1990) J. Biol. Chem. 265, 11432-11435

37. Souza, L.M., Boone, T.C., Gabliooe, J., Lai, P.H., Zsebo, K.M., Murdck, D.C., Chazin, V.R., Brusezewski, J., Lu, H., Chen, K.K., Barendt, J., Platzen, E., Moore, M.A.S., Mertelsmann, R., and Welte, K. (1986) Science 232, 610-615

38. Oh-eda, M., Hase, S., Ono, M., and Ikenaka, T. (1988) J. Biochem. (Tokyo) 103, 544-546

39. Nagata, S., Tsuchiya, M., Asano, S., Kaziro, Y., Yamazaki, T., Yamamoto, O., Hirata, Y., Kubota, N., Oheda, M., Nomura, H., and Ono, M. (1986) Nature 319, 415-418

40. Kuga, T., Komatsu, Y., Yamasaki, M., Sekine, S., Miyaji, H., Nishi, T., Sato, M., Yokoo, Y., Asano, M., Okabe, M., Morimoto, M., and Itoh, S. (1989) Biochem. Biophys. Res. Commu. 159, 103-111

41. Miyaji, H., Harada, N., Mizukami, T., Sato, S., Fujiyoshi, N., and Itoh, S. (1990) Cytotechnology 4, 173-180

42. Holmes, K.L., Palaszynski, E., Frederickson, T.N., Morse, H.C.III, and Ihle, J.N. (1985) Proc. Natl. Acad. Sci. USA 82, 6687-6691

43. Okabe, T., and Takaku, F. (1984) Cancer Res. 44, 4503-4506

44. Collen, D., Zamarron, C., Lijnen, H.R., and Hoylaerts, M. (1986) J. Biol. Chem. 261, 1259-1266

45. Ichinose, A., Fujisawa, K., and Suyama, T. (1986) J. Biol. Chem. 261, 3486-3489

46. Gurewich, V., and Pannel, R. (1987) Blood 69, 769-772

47. Lijnen, H.R., Van Hoef, B., and Collen, D. (1987) Eur. J. Biochem. 169, 359-364

48. Drickamer, K. (1988) J. Biol. Chem. 263, 9557-9560

49. Rosen, S.D., Imai, Y., Singer, M.S., and Huang, K. (1992) Trends Glycosci. Glycotechnol. 4, 1-13

50. Goelz, S.E. (1992) Trends Glycosci. Glycotechnol. 4, 14-24

51. Larsen, E. (1992) Trends Glycosci. Glycotechnol. 4, 25-31

52. Paulson, J.C., and Colley, K.J. (1989) J. Biol. Chem. 264, 17615-17618

Received on March 25, 1992; accepted on April 15, 1992 